\title{
Character Association for Seed Yield and its Contributing Traits in Blackgram [Vigna mungo (L.) Hepper]
}

\author{
Rajwanti Saran $^{1^{*}}$, P. P. Sharma ${ }^{2}$ and Harish Kumar Tank ${ }^{2}$ \\ ${ }^{1}$ Rajasthan Agricultural Research Institute, Durgapura, Jaipur-302018 (Rajasthan), India \\ ${ }^{2}$ Department of Genetics and Plant breeding, Rajasthan College of Agriculture, \\ MPUAT, Udaipur-313001 (Rajasthan), India \\ *Corresponding author
}

\section{A B S T R A C T}

In the present study, thirty five genotypes of blackgram along with two checks namely, Pratap Urd-1 and Pant urd-31 were evaluated for seed yield and its

\section{Keywords}

Blackgram,

Correlation coefficient, Path coefficient analysis

\section{Article Info}

Accepted:

15 March 2020

Available Online:

10 April 2020 contributing traits in Randomized Block Design. Investigation was carried out during Kharif 2017 to assess the correlation coefficient and path coefficient analysis. Seed yield per plant exhibited highly significant and positive correlation with number of pods per plant, biological yield per plant and harvest index both at genotypic as well as phenotypic levels similarly with number of branches per plant and number of clusters per plant at genotypic level. The positive direct effect was recorded for number of pods per plant and number of seeds per pod. High positive and indirect effect was exhibited by biological yield followed by number of branches per plant and number of clusters per plant via number of pods per plant. Hence, selection for number of pods per plant, biological yield per plant, harvest index, number of branches per plant and number of clusters per plant would result in improving the seed yield per plant.

\section{Introduction}

Pulses play a crucial role in Indian economy by virtue of their high protein content and capacity for fixing atmospheric nitrogen. Blackgram [Vigna mungo (L.) Hepper] is commonly known as urd. It is one of the most important grain legume of India which belongs to the family Fabaceae, sub-family Papilionaceae with chromosome number
$2 n=22$. India is considered as primary center of origin and central Asia as secondary center of origin of blackgram (Vavilov, 1926).

Its seeds are rich sources of protein, vitamin and minerals since they contains high seed protein $(25 \%)$, carbohydrate $(60 \%)$, fat (1.5\%), minerals $(3.2 \%)$ and vitamins viz., vitamin $A, B_{1}, B_{2}, B_{5}$ and vitamin $C$. Seed yield is a complex polygenic trait hence the 
improvement of this trait requires a huge knowledge of other yield contributing traits. The correlation coefficient measures the degree and direction of association between two variables but correlation analysis does not give exact picture of the relative importance of various yield attributes. Path coefficient analysis provides the information of the path through which a yield attributing trait influences the expression of an economic trait i.e. seed yield. It helps in splitting the correlation coefficients into direct and indirect effects of the yield attributing traits on seed yield on the basis of which improvement programmes can be carried out effectively. Hence, the present investigation was proposed with an objective to determine the character association by employing correlation coefficients and path analysis for obtaining higher yield.

\section{Materials and Methods}

The thirty five genotypes along with two checks namely, Pratap Urd-1 and Pant Urd-31 were planted during Kharif 2017 in Randomized Block Design (RBD) with three replications keeping two rows of each genotype in each replication with inter and intra row spacing of $30 \mathrm{~cm} \times 10 \mathrm{~cm}$ respectively. Recommended uniform agronomical practices were adopted for raising healthy plants. Observations were recorded on five randomly selected competitive plants taken from each plot in each replication for seed yield and its component traits viz., plant height $(\mathrm{cm})$, number of branches per plant, number of clusters per plant, number of pods per plant, number of pods per cluster, pod length $(\mathrm{cm})$, number of seeds per pod, seed yield per plant (g), biological yield per plant (g), harvest index $(\%)$, 100-seed weight $(\mathrm{g})$ and seed protein content $(\%)$ whereas, for days to 50 per cent flowering and days to 75 per cent maturity, the data was recorded on whole plot basis. Mean value was used for statistical analysis. Estimate of the genotypic and phenotypic correlation coefficients was done by using method suggested by Al-Jibouri et al., (1958). The path coefficients were calculated as per the method suggested by Dewey and Lu (1959). The seed protein content was computed through Micro Kjeldhal's method (1883).

\section{Results and Discussion}

The results obtained from analysis of variance revealed that the mean squares due to genotypes were highly significant for all the characters studied. The genotypic and phenotypic correlation between seed yield and its contributing characters and among these yield contributing characters are presented in the Table 1. In the present investigation the seed yield per plant showed highly significant and positive correlation with number of pods per plant, biological yield per plant and harvest index both at genotypic as well as phenotypic levels. Similarly it had positive and significant correlation with number of branches per plant and number of clusters per plant at genotypic level.

Similar results were also reported by Patidar and Sharma (2017), Rajasekhar et al., (2017), Mathivathana et al., (2015), Patel et al., (2014), Bharti et al., (2013) and Shivade et al., (2011). Hence, seed yield can be improved if the above these characters were given importance during selection procedure. The results of path analysis (Table 2 ) revealed that the residual effect $(\mathrm{R}=0.2511)$ indicated that 74.89 per cent variability of seed yield per plant was explained by number of branches per plant, number of clusters per plant, number of pods per plant, number of pods per cluster, pod length, number of seeds per pod and biological yield per plant. The high positive direct effect was expressed by number of pods per plant and number of seeds per pod (Fig. 1). 
Table.1 Genotypic and phenotypic correlation coefficients among various traits in blackgram (P\G)

\begin{tabular}{|c|c|c|c|c|c|c|c|c|c|c|c|c|c|c|}
\hline Character & $\begin{array}{c}\text { Days to } \\
50 \% \\
\text { flowering }\end{array}$ & $\begin{array}{c}\text { Days to } \\
75 \% \\
\text { maturity }\end{array}$ & $\begin{array}{l}\text { Plant } \\
\text { height } \\
(\mathbf{c m})\end{array}$ & $\begin{array}{c}\text { Number of } \\
\text { branches/plant }\end{array}$ & $\begin{array}{l}\text { Number of } \\
\text { clusters/plant }\end{array}$ & $\begin{array}{c}\text { Number } \\
\text { of pods/ } \\
\text { plant }\end{array}$ & $\begin{array}{l}\text { Number } \\
\text { of pods/ } \\
\text { cluster }\end{array}$ & $\begin{array}{l}\text { Pod } \\
\text { length } \\
(\mathrm{cm})\end{array}$ & $\begin{array}{l}\text { Number of } \\
\text { seeds/ pod }\end{array}$ & $\begin{array}{c}\text { Seed } \\
\text { yield/plant } \\
\text { (g) }\end{array}$ & $\begin{array}{l}\text { Biological } \\
\text { yield }(g)\end{array}$ & $\begin{array}{c}\text { Harvest } \\
\text { index } \\
(\%)\end{array}$ & $\begin{array}{l}\text { 100-seed } \\
\text { weight (g) }\end{array}$ & $\begin{array}{l}\text { Seed protein } \\
\text { content }(\%)\end{array}$ \\
\hline $\begin{array}{l}\text { Days to } 50 \% \\
\text { flowering }\end{array}$ & & -0.02 & -0.22 & -0.12 & -0.02 & 0.14 & 0.17 & $0.40 *$ & 0.17 & 0.30 & -0.05 & $0.41^{*}$ & -0.23 & -0.06 \\
\hline Days to $75 \%$ maturity & -0.11 & & -0.30 & -0.27 & -0.05 & -0.04 & 0.02 & 0.23 & -0.17 & -0.19 & -0.01 & -0.26 & $0.38^{*}$ & $0.52 * *$ \\
\hline Plant height (cm) & -0.11 & -0.22 & & -0.10 & -0.08 & -0.15 & -0.07 & $-0.37 *$ & -0.14 & -0.12 & -0.11 & -0.04 & 0.14 & 0.23 \\
\hline $\begin{array}{l}\text { Number of branches/ } \\
\text { plant }\end{array}$ & -0.05 & -0.19 & -0.06 & & $0.81 * *$ & $0.60 * *$ & $-0.47 * *$ & -0.06 & 0.16 & $0.44 * *$ & $0.49 * *$ & 0.07 & -0.02 & 0.12 \\
\hline $\begin{array}{l}\text { Number of clusters/ } \\
\text { plant }\end{array}$ & -0.09 & -0.04 & -0.04 & $0.71 * *$ & & $0.54 * *$ & $-0.69 * *$ & -0.09 & 0.15 & $0.46 * *$ & $0.43 * *$ & 0.14 & -0.01 & 0.15 \\
\hline Number of pods/plant & 0.12 & -0.02 & -0.10 & $0.52 * *$ & $0.44 * *$ & & 0.23 & -0.09 & 0.16 & $0.94 * *$ & $0.70 * *$ & $0.50 * *$ & -0.02 & -0.12 \\
\hline $\begin{array}{l}\text { Number } \\
\text { pods/cluster }\end{array}$ & 0.22 & 0.02 & -0.06 & $-0.35 *$ & $-0.68 * *$ & $0.33^{*}$ & & 0.05 & 0.02 & 0.27 & 0.09 & 0.26 & -0.02 & -0.30 \\
\hline Pod length $(\mathrm{cm})$ & 0.29 & 0.17 & -0.25 & -0.07 & -0.07 & -0.04 & 0.06 & & 0.33 & -0.24 & $-0.47 * *$ & 0.16 & 0.17 & 0.15 \\
\hline Number of seeds/pod & 0.13 & -0.05 & -0.12 & 0.12 & 0.13 & 0.06 & -0.05 & 0.23 & & 0.18 & -0.24 & $0.49 * *$ & 0.16 & -0.25 \\
\hline Seed yield/plant (g) & 0.12 & -0.07 & -0.04 & 0.30 & 0.32 & $0.62 * *$ & 0.15 & -0.14 & 0.06 & & $0.69 * *$ & $0.62 * *$ & -0.23 & -0.28 \\
\hline Biological yield (g) & -0.07 & 0.07 & -0.11 & $0.36^{*}$ & $0.33^{*}$ & $0.46^{* *}$ & 0.01 & -0.30 & -0.12 & $0.52 * *$ & & -0.14 & -0.00 & 0.01 \\
\hline Harvest index (\%) & 0.17 & -0.16 & 0.06 & 0.03 & 0.08 & 0.29 & 0.16 & 0.09 & 0.18 & $0.67 * *$ & -0.28 & & -0.31 & $-0.39 *$ \\
\hline 100-seed weight (g) & -0.18 & 0.26 & 0.11 & -0.01 & -0.01 & -0.01 & -0.02 & 0.13 & 0.12 & -0.17 & -0.00 & -0.20 & & $0.42 *$ \\
\hline $\begin{array}{l}\text { Seed protein content } \\
(\%)\end{array}$ & 0.04 & 0.30 & 0.11 & 0.08 & 0.14 & -0.08 & -0.22 & 0.14 & -0.13 & -0.17 & -0.04 & -0.16 & 0.32 & \\
\hline
\end{tabular}

$*, * *$ Significant at $5 \%$ and $1 \%$ respectively

Table.2 Direct and indirect effects of yield contributing traits on seed yield per plant

\begin{tabular}{|c|c|c|c|c|c|c|c|c|}
\hline Character & $\begin{array}{c}\text { Number of } \\
\text { branches/plant }\end{array}$ & $\begin{array}{c}\text { Number of } \\
\text { clusters/plant }\end{array}$ & $\begin{array}{l}\text { Number of } \\
\text { pods/plant }\end{array}$ & $\begin{array}{l}\text { Number of } \\
\text { pods/cluster }\end{array}$ & $\begin{array}{l}\text { Pod length } \\
\quad(\mathrm{cm})\end{array}$ & $\begin{array}{l}\text { Number of } \\
\text { seeds/pod }\end{array}$ & $\begin{array}{l}\text { Biological } \\
\text { yield (g) }\end{array}$ & $\begin{array}{c}\text { Genotypic correlation } \\
\text { coefficient }\end{array}$ \\
\hline Number of branches/plant & -0.30 & -0.23 & 0.84 & 0.17 & 0.01 & 0.02 & -0.06 & $0.44 * *$ \\
\hline Number of clusters/plant & -0.25 & -0.29 & 0.76 & 0.25 & 0.02 & 0.02 & -0.05 & $0.46 * *$ \\
\hline Number of pods/plant & -0.18 & -0.16 & 1.41 & -0.08 & 0.02 & 0.02 & -0.09 & $0.94 * *$ \\
\hline Number of pods/cluster & 0.14 & 0.20 & 0.32 & -0.37 & -0.01 & 0.00 & -0.01 & 0.27 \\
\hline Pod length (cm) & 0.02 & 0.03 & -0.13 & -0.02 & -0.23 & 0.03 & 0.06 & -0.24 \\
\hline Number of seeds/pod & -0.05 & -0.04 & 0.22 & -0.01 & -0.08 & 0.10 & 0.03 & 0.18 \\
\hline Biological yield (g) & -0.15 & -0.12 & 0.99 & -0.03 & 0.11 & -0.02 & -0.13 & $0.69 * *$ \\
\hline
\end{tabular}

Residual $=0.2511$, Bold figures in main diagonal indicate direct effects 


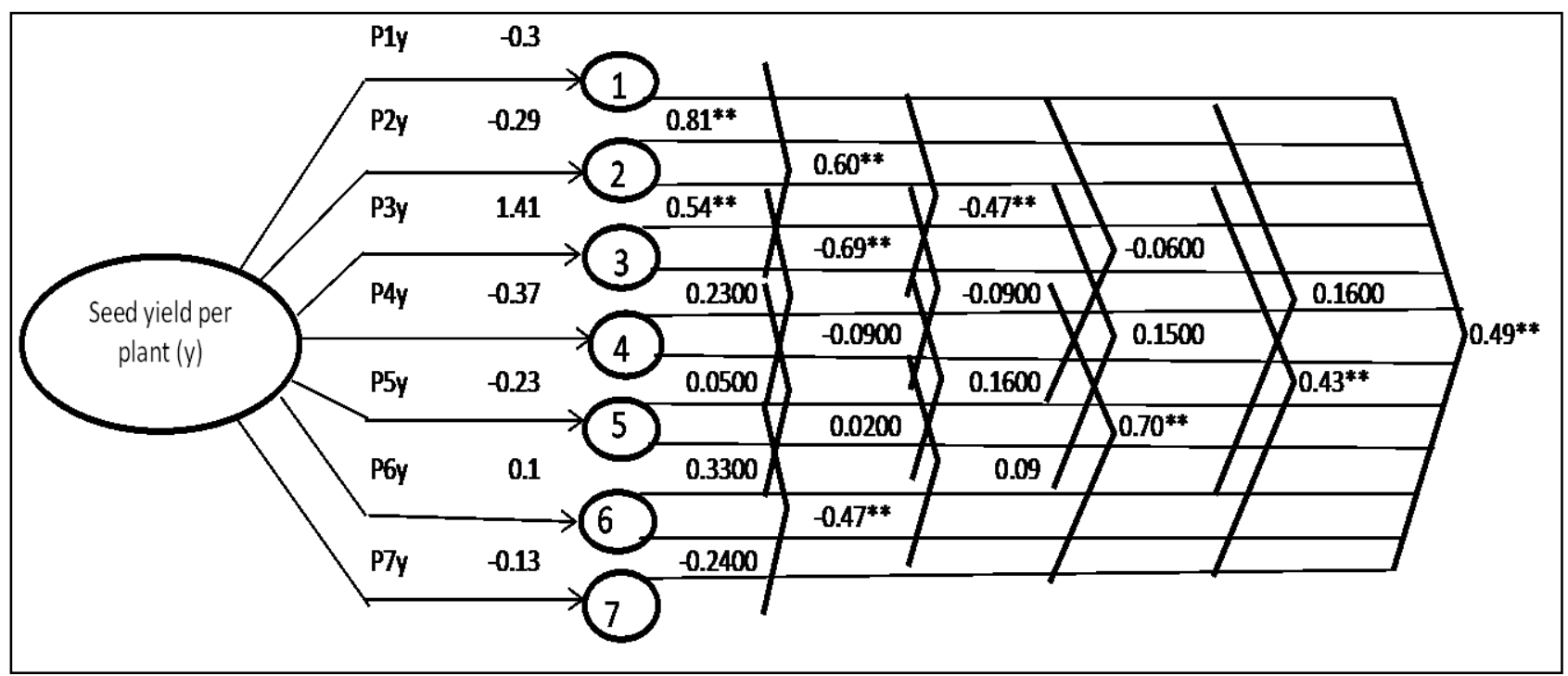

Figure.1 Genotypic path diagram for seed yield per plant

Therefore, selection on these characters will be helpful in increasing the seed yield of blackgram. Similar findings were reported by Sohel et al., (2016), Gowsalya et al., (2016) and Arya et al., (2017). The negative direct effect exhibited by number of pods per cluster, number of branches per plant, number of clusters per plant, pod length and biological yield.

The seed yield showed high positive and significant correlation with number of branches per plant, number of clusters per plant and biological yield. It is mainly due to the high positive indirect effects of these characters via number of pods per plant and some other characters. Hence, indirect selection for these characters will be useful in further improvement of blackgram genotypes.

Based on results of correlation and path coefficient analysis, it can be concluded that improvement in seed yield of blackgram is brought through selection for number of pods per plant, harvest index, number of branches per plant, biological yield per plant, number of clusters per plant and number of seeds per pod.

\section{References}

Al-Jibouri, H. A., Miller, P. A. and Robinson, H. F. 1958. Genotypic and environmental variance in upland cotton of interspecific origin. Agronomy Journal, 50: 633-663.

Arya, P., Gaibriyal, M. L. and Sapna, S. L. 2017. Correlation and path analysis for yield and yield components in blackgram (Vigna mungo). International Journal of Advanced Biological Research, 7: 382-386.

Bharti, B., Kumar, R., Bind, H. N., Kumar, A. and Sharma, V. 2013. Correlation and path analysis for yield and its components in blackgram (Vigna mungo L.). Society for Science Development in Agriculture and Technology, 8: 473-476.

Dewey, D. R. and Lu, K. H. 1959. A correlation and path coefficient analysis of components of wheat grass seed production. Journal of Agronomy, 51: 515-518.

Mathivathana, M. K., Shunmugavalli, N., Muthuswamy, A. and Vijulan Harris, C. 2015. Correlation and path analysis in blackgram. Agricultural Research 
Communication Centre, 35: 158-160.

Patel, S. R., Patel, K. K. and Parmar, H. K. 2014. Genetic variability, correlation and path analysis for seed yield and its components in green gram (Vigna radiata (L.) Wilczek). International Journal of Life Science, 9: 1847-1852.

Patidar, M. and Sharma, H. 2017. Correlation and path coefficient studies in blackgram (Vigna mungo (L.) Hepper). Journal of Pharmacognosy and Phytochemistry, 6: 1626-1628.

Rajasekhar, D., Lal, S. S. and Lal, G. M. 2017.Character association and path analysis for seed yield and its components in blackgram [Vigna mungo (L.) Hepper]. Plant Archives, 17: 467-471.

Shivade, H. A., Rewale, A. P. and Patil, S. B. 2011. Correlation and path analysis for yield and yield components in blackgram [Vigna mungo (L.) Hepper].
Legume Research, 34: 178 -183.

Sohel, M. H., Miah, M. R., Mohiuddin, S. J., Sajjadul Islam, A. K. M., Rahman, M. M. and Haque, M. A. 2016. Correlation and path coefficient analysis of blackgram (Vigna mungo (L.) Hepper). Journal of Bioscience and Agriculture Research, 7: 621-629.

Gowsalya, P., Kumaresan, D., Packiaraj, D. and Kannanbapu, J.R. 2016. Genetic variability and character association for biometrical traits in blackgram (Vigna mungo (L.) Hepper). Electronic Journal of Plant Breeding, 7: 317-324.

Kjeldahl, J. 1883. A new method for the estimation of nitrogen in organic compounds. Journal of Annals Chemistry, 22: 366.

Vavilov, N.I. 1926. Origin variation, immunity of cultivated plants. Chronica Botanica, 13: 364.

\section{How to cite this article:}

Rajwanti Saran, P. P. Sharma and Harish Kumar Tank. 2020. Character Association for Seed Yield and its Contributing Traits in Blackgram [Vigna mungo (L.) Hepper]. Int.J.Curr.Microbiol.App.Sci. 9(04): 2029-2033. doi: https://doi.org/10.20546/ijcmas.2020.904.242 